\title{
Legal Considerations in Sign Code Development
}

Alan Weinstein

Professor,

Cleveland-Marshall College of Law

Maxine Goodman Levin College of Urban Affairs 
A. Weinstein

Legal Considerations in Sign Code Development

Interdisciplinary Journal of Signage and Wayfinding; Volume 2; Issue 1

Legal considerations have always played a critical role in the development of a sign code, but that role has taken on renewed importance in the wake of the U.S. Supreme Court's recent ruling in Reed v. Town of Gilbert, Ariz., 135 S.Ct. 2218 (2015). A detailed analysis of Reed is obviously beyond the scope of this paper. ${ }^{1}$ For our purposes, it is sufficient to note that the Reed Court announced a far more stringent test to determine whether a sign code's provisions are "content-neutral" or "content-based." In short, the Court ruled that any sign code provision that "on its face" considers the message on a sign to determine how it will be regulated is contentbased. $^{2}$ The practical effect of finding that a sign code provision is content-based is to heighten the judicial scrutiny of such a provision if challenged. A provision that is content-neutral is subjected only to intermediate judicial scrutiny: the provision will be upheld if government can demonstrate that the regulation serves a substantial governmental interest and is narrowlytailored to achieve that interest. In contrast, a provision that is content-based is subjected to strict judicial scrutiny: the provision will be upheld only if government can demonstrate that the regulation serves a compelling governmental interest and is the least restrictive alternative to achieve that interest. ${ }^{3}$

A case exemplifying how much Reed has affected court review of sign regulations that contain content-based provisions, normally found in "exemptions" is Central Radio Co. Inc. v. City of Norfolk, Va. ${ }^{4}$ There, in a challenge first decided before Reed, the Fourth Circuit Court of

\footnotetext{
${ }^{1}$ For a comprehensive analysis of the Reed decision, see Brian J. Connolly and Alan C. Weinstein, Sign Regulation After Reed: Suggestions for Coping with Legal Uncertainty, 47 Urb. Law. 569 (2015) in which portions of this articled were previously published.

${ }^{2}$ Reed v. Town of Gilbert, Ariz., 135 S.Ct. 2218, 2227 (2015).

${ }^{3}$ Strict scrutiny normally leads to the invalidation of the challenged provision since few courts have found that traffic safety or aesthetics, the governmental interests normally used to support sign regulation, are compelling interests. Further, most sign codes cannot demonstrate that a challenged provision is the least restrictive alternative. See, Connolly \& Weinstein, n. 1 supra at 605-608.

${ }^{4}$ Central Radio Co. Inc. v. City of Norfolk, Va., 811 F.3d 625 (4th Cir. 2016).
} 
A. Weinstein

Legal Considerations in Sign Code Development

Interdisciplinary Journal of Signage and Wayfinding; Volume 2; Issue 1

Appeals had concluded that a sign regulation exempting flags, emblems and works of art was content-neutral and, applying intermediate scrutiny, held that the regulation was a constitutional exercise of the city's regulatory authority. ${ }^{5}$ But when the challenge was renewed after Reed, the Court of Appeals reversed its decision and agreed with the plaintiffs that, under Reed, the regulation was a content-based restriction that cannot withstand strict scrutiny. ${ }^{6}$ Similarly, in Wagner v. City of Garfield Heights, ${ }^{7}$ the Sixth Circuit had first reversed a district court ruling that the city's restrictions on political signs was content-based regulation that violated the first amendment under strict scrutiny. After granting certiorari, the Supreme Court vacated the Sixth Circuit's judgment and remanded for reconsideration under Reed. The Sixth Circuit on remand applied strict scrutiny and found that the ordinance was not narrowly tailored to achieve the city's asserted interests in aesthetics and traffic safety.

While the Supreme Court's Reed decision is still fairly new and the decision's complete impact remains to be seen, when developing sign codes lawyers, planners, and local government officials can take steps to minimize legal risk in the wake of the court's decision. Even before Reed, most local sign codes contained at least some provisions of questionable constitutionality, and the fact is that developing a $100 \%$ content neutral sign code may be impossible for some, or even most, local governments. Further, as Justice Kagan's concurring opinion in Reed noted, such a code might not function well in addressing legitimate aesthetic and traffic safety

\footnotetext{
${ }^{5}$ Central Radio Co. Inc. v. City of Norfolk, Virginia, 776 F.3d 229 (4th Cir.2015), cert. granted, judgment vacated, sub nom. Cent. Radio Co. Inc. v. City of Norfolk, Va.135 S. Ct. 2893, 192 L. Ed. 2d 919 (2015).

${ }^{6}$ Central Radio Co. Inc. v. City of Norfolk, Va., 811 F.3d 625 (4th Cir. 2016). See also Geft Outdoor LLC v. Consolidated City of Indianapolis and County of Marion, Indiana, 187 F. Supp. 3d 1002 (S.D. Ind. 2016) (noting amendment of ordinance to comply with Reed).

${ }^{7}$ Wagner v. City of Garfield Heights, 675 Fed. Appx. 599 (6th Cir. 2017). See also Marin v. Town of Southeast, 136 F. Supp. 3d 548 (S.D.N.Y. 2015) (ruling that a regulation that exempted certain signs, but not political signs, from restrictions placed on temporary signage, was a content-based restriction that did not withstand strict scrutiny).
} 
A. Weinstein

Legal Considerations in Sign Code Development

Interdisciplinary Journal of Signage and Wayfinding; Volume 2; Issue 1

concerns. ${ }^{8}$ Sign code drafting is an often imprecise exercise, subject to the influences of planning, law, and, perhaps most importantly, local politics. Planners and local government lawyers should therefore view sign regulation with an eye toward risk management. If the local government is willing to tolerate some degree of legal risk, it may be appropriate to take a more aggressive, if less constitutionally-tested approach to sign regulation. Conversely, if the local government is unwilling to accept the risks associated with more rigorous regulation of signs, it would be advisable to adopt a more strictly content neutral — if less aesthetically effectiveapproach.

In a risk management approach to sign regulation, the local government's adopted regulations should reflect a balance between the community's desire to achieve certain regulatory objectives and the community's tolerance for legal risk. Regardless of some of the uncertainties that remain about the substantive reach of the Reed decision, ${ }^{9}$ Reed clearly increases the level of legal risk associated with many aspects of sign regulation, and most particularly regulation of non-commercial signs. Thus, while communities are well-advised to review sign regulations for potential areas of content discrimination and to take precautions against potential sign litigation, when developing a sign code communities should also consider (or perhaps reconsider) the level of legal risk that the community is willing to tolerate in order to achieve the community's aesthetic goals and interests in traffic safety. In some areas of sign regulation and for some local jurisdictions, achieving aesthetic goals may run counter to minimizing legal risk, and it will be up to planners, lawyers, political leaders, and community

\footnotetext{
${ }^{8}$ Reed v. Town of Gilbert, Ariz., 135 S.Ct. at 2236-2239.

${ }^{9}$ See, Connolly \& Weinstein, n. 1 supra at 587-610.
} 
A. Weinstein

Legal Considerations in Sign Code Development

Interdisciplinary Journal of Signage and Wayfinding; Volume 2; Issue 1

members to determine the appropriate balance between the community's desired planning outcomes and the community's risk tolerance.

In all communities, special care should be taken to avoid regulating signs that have minimal impact on the community's established interests in sign regulation. For example, avoiding regulation of signs which are not visible from a public right-of-way, or which are so as to have a negligible visual impact, is good sign regulation practice and is in keeping with the notion that regulations should only go as far as necessary to further the interests of the regulating body. In the same vein, communities should focus on addressing "problem areas" of sign regulation specific to the community instead of regulating for problems that do not exist. Employing this approach to sign regulation will likely result in the outcomes desired by the community while providing an appropriate level of protection against costly and time-consuming litigation. With these observations in mind, here is some practical advice on dealing with legal issues in sign code development and regulation in the post-Reed world.

\section{A. Review Your Current Sign Code for Content-Based Provisions}

Because local sign codes frequently contain at least some areas of content bias, a community should undertake a painstaking review of its current sign code to determine where and how the code exhibits the forms of content discrimination called into question by Reed. Local sign codes are often an amalgam of regulatory provisions enacted to respond to discrete sign regulation problems that have previously arisen. Further, "common sense" reactions to many sign regulation problems may raise the greatest problems in First Amendment analysis; for example, addressing a proliferation of temporary political signs by imposing strict regulations on such signs would likely prove problematic if scrutinized by a court following Reed. 
A. Weinstein

Legal Considerations in Sign Code Development

Interdisciplinary Journal of Signage and Wayfinding; Volume 2; Issue 1

Where a municipal attorney or local planner lacks certainty as to whether a particular provision is content neutral, contact a lawyer well-versed in First Amendment issues and sign regulation. Even if a sign code "fix" is not possible in the near term, knowing the sign code's areas of vulnerability, and coaching permitting and enforcement staff to limit potential problems, can be a crucial step toward protecting a local government from liability.

To guide the process of reviewing local codes for content based provisions, here is a short list of critical areas to review for existing codes and to consider in developing a new code.

\section{Review and Consider Eliminating Exceptions to Permitting Requirements}

Exceptions to permitting requirements are common features of sign codes, but these exceptions often raise constitutional problems. The Gilbert, AZ sign code at issue in Reed mirrored many other codes in having a general requirement that all signs obtain a permit, with several categories of excepted signs. ${ }^{10}$ Exceptions from permitting can be problematic from both a content neutrality and narrow tailoring perspective. On the content neutrality side, local governments should closely review how the excepted signs are defined. For example, are there exceptions to permitting requirements for political signs, election signs, campaign signs, religious signs, real estate signs, construction signs, address signs, governmental flags, or any other types of signs that might be defined by the message(s) displayed on the signs? ${ }^{11}$

\footnotetext{
${ }^{10}$ See, e.g., DENVER, COLO. ZONING CODE $§ 10.10 .3 .1$ (containing a list of signs not subject to a permit).

${ }^{11}$ See, e.g., Central Radio Co., Inc. v. City of Norfolk, VA, 776 F.3d 229 ( $4^{\text {th }}$ Cir. 2015), cert. granted, judgment vacated, 135 S.Ct. 2893 (2015), reversed, 811 F.3d 625 ( $4^{\text {th }}$ Cir. 2016)(ruling that sign code exempting certain displays, including any "flag or emblem" of any government or "religious organization" and "works of art" that do not identify/relate to a product or service was a content-based restriction that did not withstand strict scrutiny) and Marin v. Town of Southeast, 136 F.Supp.3d 548 (S.D.N.Y. 2015) (finding that regulation that exempted certain signs, but not political signs, from restrictions placed on temporary signage, was a content-based restriction that did not withstand strict scrutiny).
} 
A. Weinstein

Legal Considerations in Sign Code Development

Interdisciplinary Journal of Signage and Wayfinding; Volume 2; Issue 1

On the narrow tailoring side, local governments should consider whether the exceptions to permitting requirements further the asserted purpose for the sign code or are at least sufficiently limited to avoid undercutting the stated purpose. For example, if a code contains the express goal of eliminating sign clutter to improve traffic safety and aesthetics, does allowing "Grand Opening Signs" somehow nullify that aesthetic interest—or nullify the government's interest in prohibiting myriad other temporary signs? Or if a code allows certain types of unpermitted noncommercial signs to be larger than real estate signs, is the government undermining its general interest in reducing driver distractions (since drivers can be distracted just as easily by political signs as by real estate signs)? Removing content-based definitions from exceptions to permitting requirements, and reconsidering whether the exceptions undermine the regulatory purposes of the sign code will assist local governments in mitigating liability going forward.

Clearly, After Reed, exceptions to permitting requirements are extremely problematic. It follows that the number of permitting exceptions should be reduced wherever possible, while maintaining those permitted exceptions - and their definitions - that are necessary to reduce litigation risk or achieve stated goals of the sign code. The same holds true for differentiallytreated categories of signs. The sign code in Reed contained 23 categorical exceptions to the town's basic permitting requirement. Regardless of the rationales for the enactment of these 23 exceptions, one can assume that at least some of these exceptions - and the differential treatment between the various categories of exceptions-were unnecessary to achieve the code's stated goals of traffic safety and community aesthetics. My experience in sign regulation strongly suggests that excessive "slicing and dicing" of sign categories frequently leads to more litigation 
A. Weinstein

Legal Considerations in Sign Code Development

Interdisciplinary Journal of Signage and Wayfinding; Volume 2; Issue 1

and liability for local governments. Thus, local governments are encouraged to exercise restraint in creating permitting exceptions and avoid multiple categories of permitted exceptions.

The foregoing is not to say, however, that local governments should avoid all exceptions to permitting and require permits for all signs. Permitting requirements carry additional constitutional obligations for local governments, most importantly the obligation to avoid unconstitutional prior restraints on speech. For a permitting requirement to avoid such concerns, it should contain adequate procedural safeguards. Such a requirement should provide strict yet brief review timeframes to which the local government must adhere and must not vest unbridled discretion in local government officials, i.e., the code should contain clearly-articulated approval criteria for signs subject to a permit. ${ }^{12}$ If a local government opts to require that noncommercial signs be permitted prior to installation, the code should avoid content discrimination in the requirements for permitted noncommercial signs. Precisely because of prior restraint concerns and the sensitivity of noncommercial sign owners to prior restraints, many local governments opt to except certain forms of noncommercial signage from permitting requirements. If the sign code drafters desire to except political signs from a permitting requirement, that exception—and the treatment of the excepted signs in terms of size, height, lighting, etc.- -should apply equally to all noncommercial signs, regardless of the message on the sign.

\section{2. $\quad$ Remove/Avoid "Problem" Definitions}

To avoid post-Reed liability associated with certain types of noncommercial speech, local governments should remove or reconsider potentially problematic categories and definitions in sign codes. Some of these problem definitions include "political signs," "religious signs," "event

\footnotetext{
${ }^{12}$ See, e.g., Café Erotica of Fla., Inc. v. St. Johns Cnty., 360 F.3d 1274, 1282 (11th Cir. 2004); Lusk v. Vill. of Cold Spring, 475 F.3d 480, 485-87 (2d Cir. 2007).
} 
A. Weinstein

Legal Considerations in Sign Code Development

Interdisciplinary Journal of Signage and Wayfinding; Volume 2; Issue 1

signs," "real estate signs," and "holiday lights." These categories are problematic for two reasons. First, when used in local sign codes, these categories typically rely upon the subject matter or message of the sign itself to define the category, which is presumptively unconstitutional after Reed, thus giving rise to potential liability for the government. ${ }^{13}$ The second reason is that, in most cases, these categories relate to core First Amendment-protected speech, with concomitant heightened public sensitivity that can easily lead to litigation. Whereas many commercial business owners are disinclined to spend time and money litigating over sign regulations, individuals and not-for-profit organizations, many of whom are represented by pro bono legal counsel in First Amendment cases, are inclined to spend time and money to preserve core First Amendment rights. ${ }^{14}$ Reed is a perfect example: the litigation lasted eight years, and Pastor Reed and Good News were represented by pro bono legal counsel. ${ }^{15}$

In some cases, the problem areas can be regulated with sign code definitions that do not directly control or restrict the content of the sign in question. As discussed above, a potentially content neutral definition of "real estate sign" could be "a temporary sign posted on property that is actively marketed for sale." Such a definition does not address the content of the sign, but rather deals with the status of the property and location of the sign. Thus, a for-sale property could theoretically be posted with a "Save the Whales" sign under this definition, but it is likely that the economic motives of the seller would dictate otherwise. While this approach lowers legal risk, it does not eliminate it. If such a provision were challenged, a plaintiff might

\footnotetext{
${ }^{13}$ See Reed, 135 S. Ct. at 2227.

${ }^{14}$ Because First Amendment challenges to sign codes are normally brought under the Civil Rights Act, 42 U.S.C. $\S$ 1983, which allows for the award of attorneys' fees under 42 U.S.C. $\S 1988$, pro bono - and other - counsel may be very interested in representing plaintiffs in these challenges. See, e.g., Cleveland Area Bd. of Realtors v. City of Euclid, 965 F. Supp. 1017, 1026 (N.D. Ohio 1997) (awarding $\$ 308,825.70$ in attorneys' fees and costs in sign code case). Adjusting for inflation, that award is equal to $\$ 457,225.60$ in current dollars.

${ }^{15}$ They were represented pro bono by the Alliance Defending Freedom. See, "Vital Signs" available on the Alliance website: adflegal.org.
} 
A. Weinstein

Legal Considerations in Sign Code Development

Interdisciplinary Journal of Signage and Wayfinding; Volume 2; Issue 1

successfully claim that the purpose for the facially content-neutral definition was to allow for the display of real estate signs, which would then subject the provision to strict scrutiny. Similarly, if the definition of "event sign" is "a temporary sign displayed within 500 feet of property on which a one-time event is held, and which sign may be displayed for up to five days before and one day after such event," the "event sign" could read "Smoke Grass," but the event proponent's interest in promoting the event would likely win the day.

In other cases, some of the problem sign types should simply be avoided. For example, it is nearly impossible to define "political sign" or "religious sign" in a manner that does not create serious content bias issues. If a community has concerns regarding proliferation of these sign types, the problem is best addressed with regulations applicable to all noncommercial signs. As Reed espouses, it is not within the purview of local government to pick and choose the subject matter or message of noncommercial speech, or to favor certain types of noncommercial speech over others. To the extent local political leaders are concerned about proliferations of political or religious signs, lawyers and planners should endeavor to educate political leaders about the risks associated with sign regulations of this nature.

\section{B. Avoid Strict Enforcement of Content Based Distinctions and Moratoria}

Local governments are also well-advised to suspend enforcement of code provisionsparticularly regulation of non-commercial signs - that Reed calls into question. This obviously does not include any structural and locational provisions in the sign code directly related to public safety. All of these should continue to be enforced. In a case decided shortly before Reed, a federal court upheld an Oregon county's decision to cease enforcement of content based 
A. Weinstein

Legal Considerations in Sign Code Development

Interdisciplinary Journal of Signage and Wayfinding; Volume 2; Issue 1

provisions in the county code ${ }^{16}$ and to instead review applications for temporary sign permits under the remaining, content neutral provisions of the code. ${ }^{17}$ This decision provides a superb road map for a jurisdiction considering how it might administer, in the near term, a content based local sign code.

Some local governments may believe that a prudent response to Reed is to enact a moratorium on the issuance of sign permits during the pendency of code revisions. That approach is problematic. If challenged, a moratorium, would in most circumstances constitute an unconstitutional prior restraint on expression. ${ }^{18}$ Courts strongly disfavor moratoria on issuing any sign permits or, worse yet, displaying any new signs. In contrast, a moratorium of short duration - certainly no more than 30 days - that is narrowly tailored to address only the issues raised by Reed might possibly be upheld. The authors, however, do not recommend this approach.

\section{Ensure that Sign Codes Contain the Three "Basic" Sign Code Requirements}

While acknowledging the complexity inherent in sign regulation following Reed, there are three easy steps that communities can take to reduce legal risk associated with sign code litigation.

\section{1. $\quad$ Purpose Statement}

All sign codes should have a strong, well-articulated purpose statement to pass constitutional muster. Although Reed rejected the notion that a content neutral purpose is

\footnotetext{
16 See Icon Groupe, LLC v. Washington Cnty. 2015 WL 3397170, at *8, *13 (D. Or. 2015).

${ }^{17} \mathrm{Id}$. at $* 13$.

${ }^{18}$ See, e.g., Schneider v. City of Ramsey, 800 F.Supp. 815 (D.Minn. 1992), aff'd sub nom. Holmberg v. City of Ramsey, 12 F.3d 140, 144-45 (8th Cir. 1994) (invalidating, as prior restraint, moratorium passed to allow city time to draft zoning regulations for adult uses); Howard v. City of Jacksonville, 109 F. Supp. 2d 1360, 1365 (M.D. Fla. 2000) (finding a moratorium on the issuance of permits for adult entertainment businesses invalid as an unconstitutional prior restraint on expression).
} 
A. Weinstein

Legal Considerations in Sign Code Development

Interdisciplinary Journal of Signage and Wayfinding; Volume 2; Issue 1

sufficient to withstand a First Amendment challenge to a content-based provision, governmental intent remains an important factor in sign code drafting and litigation. ${ }^{19}$ After all, the first prong of both the intermediate scrutiny and strict scrutiny tests focuses on whether the government is seeking to advance a "significant" (intermediate) or "compelling" (strict) regulatory interest. ${ }^{20}$

In Metromedia ${ }^{21}$ the Supreme Court upheld both traffic safety and community aesthetics as significant governmental interests sufficient to satisfy intermediate scrutiny. Since that time, it has been standard practice for local governments to articulate traffic safety and aesthetics as regulatory interests supporting sign regulations. Although these are certainly the most-recited regulatory interests in local sign codes, and the ones most routinely acknowledged by courts as meeting the intermediate scrutiny test's requirement of a significant governmental interest, other regulatory interests may suffice as well. Such regulatory interests might include blight prevention, economic development, design creativity, prevention of clutter, protection of property values, encouragement of free speech, and scenic view protection. ${ }^{22}$

\section{2. $\quad$ Substitution Clause}

The second "basic" sign code requirement is a so-called "substitution clause." A substitution clause is designed to avoid unconstitutional, content based preferences for commercial speech over noncommercial speech resulting from bans or limitations on offpremises signage, or generous allowances for certain commercial signs. A substitution clause expressly allows noncommercial content to replace the message on any permitted or exempt

\footnotetext{
${ }^{19}$ In Desert Outdoor Advertising v. City of Moreno Valley, the Ninth Circuit struck down a local sign ordinance simply on the grounds that it failed to articulate a regulatory purpose. 103 F.3d 814, 819 (9th Cir. 1996). A local government's articulation of a regulatory purpose provides an evidentiary basis for the first prong of the intermediate and strict scrutiny tests.

${ }^{20}$ See Reed, 135 S. Ct. at 2231.

${ }^{21}$ Metromedia, Inc. v. City of San Diego, 453 U.S. 490 (1981).

${ }^{22}$ See Brian J. Connolly \& Mark A. Wyckoff, Michigan Sign Guidebook: The Local Planning AND REGULATION OF SIGNS, 12-3, 13-3 (2011), available at http://scenicmichigan.org/sign-regulation-guidebook.
} 
A. Weinstein

Legal Considerations in Sign Code Development

Interdisciplinary Journal of Signage and Wayfinding; Volume 2; Issue 1

sign. ${ }^{23}$ For example, where a sign code allows onsite signs for, say, big-box retailers to be larger than other signs allowed in the community, the message substitution clause allows the big box retailer to replace the onsite sign with a noncommercial message advocating a political position or supporting a particular cause, avoiding the constitutional problem that would otherwise arise if a commercial sign were permitted to the exclusion of a noncommercial sign. ${ }^{24}$

\section{Severability Clause}

Severability clauses are added to sign regulations - and statutory provisions more broadly — to uphold the balance of a code in the event a court finds a particular provision invalid. ${ }^{25}$ In the context of sign regulations, severability clauses have always been extremely important and are even more so after Reed. ${ }^{26}$ Facial challenges to sign codes are more common than facial challenges to zoning codes or other local regulations. Severability clauses hedge against the possibility that a court will rule that a sign code is invalid in its entirety rather than merely invalidating one or more provisions. Without a severability clause, an invalidated sign code could result in a regulatory vacuum without sign regulations, forcing local governments to either allow all signs — an aesthetic anarchy from which recovery would be difficult—or to adopt roughshod regulations or moratoria that could cause additional constitutional problems. For

\footnotetext{
${ }^{23}$ See, e.g., Daniel R. Mandelker, Andrew Bertucci \& William Ewald, Street Graphics AND THE LAW 51, PlanNING AdVISORY SERV. ReP. No. 527, (Am. Plan. Ass'n rev. ed. 2004).

${ }^{24}$ Many of the problems of the Gilbert sign code at issue in Reed would have been resolved with a strong substitution clause, although it is questionable whether such a clause would have achieved the town's pre-Reed regulatory objectives.

${ }^{25}$ See, e.g., BoERnE, TEX., Sign ORdinANCE $\S 18$ (2008) ("If any portion of this ordinance or any section or subdivision thereof be declared unconstitutional or in violation of the general laws of the state, such declaration shall not affect the remainder of this ordinance which shall remain in full force and effect."); CITY OF FARMINGTON, MICH. ZONING ORDINANCE $§ 35-233$ ("This chapter and the various components, articles, sections, subsections, sentences and phrases are hereby declared to be severable. If any court of competent jurisdiction shall declare any part of this chapter to be unconstitutional or invalid, such ruling shall not affect any other provision of this chapter not specifically included in said ruling.").

${ }^{26}$ Even if the sign code is contained within the zoning code, the authors strongly recommend a separate severability clause be placed in the sign code.
} 
A. Weinstein

Legal Considerations in Sign Code Development

Interdisciplinary Journal of Signage and Wayfinding; Volume 2; Issue 1

these reasons, adopting a severability clause into the sign code is an important protective step for local governments to take.

\section{Apply an Empirical Approach to Justify Sign Regulations, Where Possible}

Sign codes require justification with purpose statements. Recitations of regulatory purposes should be supported by some form of empirical study or data. Short, glib statements regarding regulatory purposes do not reflect any degree of thoughtfulness regarding sign regulations, and they leave a local government without evidentiary support for its stated purposes in the event of litigation. To that end, local governments should consider employing at least some study and analysis in preparing regulatory purpose statements. Two approaches are discussed below. Using a comprehensive planning process to identify aesthetic concerns generated by signage, or employing traffic safety analysis can assist in purpose statement preparation.

\section{1. $\quad$ Traffic Safety Studies}

While many local sign codes recite traffic safety as a central purpose for sign regulation, very few substantiate the conclusion that a proliferation of signs - or certain types of signs-has actually caused traffic safety concerns in the community. Indeed, some lawyers and sign industry advocates have questioned whether signs - particularly in a world of smart phones, navigation systems, and other driver distractions - contribute at all to driver distraction and traffic incidents. Local governments are therefore advised to conduct studies, or at least consult studies prepared by national experts, to more carefully determine the safety concerns associated with outdoor signage. ${ }^{27}$ Local government fire and safety personnel may also be helpful in

27 See, e.g., Federal Highway Admin., The EfFects of Commercial Electronic Variable Message Signs (CEVMS) ON Driver ATtention AND Distraction: AN UpDATe, Publ'n No. FHWA-HRT-09-018 (Feb. 2009), 
A. Weinstein

Legal Considerations in Sign Code Development

Interdisciplinary Journal of Signage and Wayfinding; Volume 2; Issue 1

documenting, even if only anecdotally, their concerns about traffic safety issues associated with too much or too little signage. For example, employing traffic safety study data or documentation provided by fire and safety personnel to determine the appropriate location, height, size, brightness, etc. of signage along major thoroughfares provides a local government with the type of evidence required to craft sign regulations that respond to stated traffic safety concerns, as well as the evidentiary support necessary to defend a sign code in the event of litigation.

\section{Comprehensive Planning}

Comprehensive planning is another source of empirical study that can be used to justify and defend sign codes. Signs are not often the focus of comprehensive planning, however, the visual impact of signs on communities and corridors weighs in favor of including sign issues in communities' land use planning processes. To the extent signs are addressed in a local comprehensive plan, the plan can help to identify and direct sign regulation toward the most pressing sign issues in the community. Moreover, a good comprehensive plan containing robust analysis of sign issues in the community provides good evidentiary support in sign code litigation.

\section{E. Regulation of Sign Function in a Content Neutral World: Construction Signs, Real Estate Signs, Wayfinding Signs, Political/ideological Signs, etc.}

Perhaps the most vexing post-Reed problem faced by local jurisdictions is how to continue to regulate signs according to function or category without becoming crosswise with a district court judge. For some communities, it may be possible to avoid functional sign regulation altogether through uniform regulations of temporary signs-regardless of message. 
A. Weinstein

Legal Considerations in Sign Code Development

Interdisciplinary Journal of Signage and Wayfinding; Volume 2; Issue 1

For other jurisdictions, however, that may not be possible for various planning or political reasons.

Reed condemns all facial distinctions between messages, including those that "are more subtle, defining regulated speech by its function or purpose."28 Therefore, as a starting point, local governments must avoid defining functional sign types according to the language or message that appears on the face of the sign. By now, it should be clear that establishing distinct rules for political, religious, or ideological signs is virtually impossible without engaging in content regulation. A local government that maintains regulations specific to these sign types risks treating forms of noncommercial messages differently, which may precipitate a sign code challenge. As much as some local politicians may wish to see regulation of political signs, specialized political sign regulations are simply barred after Reed.

This is not to say, however, that local governments cannot regulate signs according to structural, temporal, or other time, place, and manner-type distinctions. For example, local governments may still regulate permanent signs differently from temporary signs in a content neutral manner. These signs are easily distinguished based on structural characteristicspermanent signs are permanently affixed to the ground, a wall, or some other device, while temporary signs are not. Permanent and temporary signs may also be made of different materials; permanent signs are frequently made of stone, metal or wood, while temporary signs are predominantly made of plastic or cardboard. Local governments may also regulate display time for temporary signs. It is not unconstitutional for a local government to say, for example, that a temporary sign may be placed for a maximum of 90 days at a time. Moreover, sign

${ }^{28}$ Reed, 135 S. Ct. at 2227. 
A. Weinstein

Legal Considerations in Sign Code Development

Interdisciplinary Journal of Signage and Wayfinding; Volume 2; Issue 1

regulations may continue to place size limits and numerical limits on total amount of signage per property.

It is therefore not inconceivable to think that a local government could regulate political, ideological and other forms of noncommercial signage as follows: "Notwithstanding any other provision of this code, each parcel of real property shall be allowed, without a permit, an additional thirty two (32) square feet of temporary noncommercial signage, not to exceed four (4) signs at any one time, for a period not to exceed ninety (90) days per calendar year." This provision would allow non-permitted, temporary, noncommercial signage, but restrict that signage to certain size and number requirements, and to a certain display time. Moreover, this code provision is content neutral, as it does not limit or restrict what the sign might say-except that it must be noncommercial.

While the foregoing code provision would likely satisfy Reed, it may be difficult to enforce and may not accomplish all of the objectives of the local government. Another approach, albeit one with greater risk exposure, is to define signs according the activities occurring where the sign is located. For example, a content neutral definition of a "construction sign" might be "a temporary sign placed within a parcel of property upon which construction activities of any type are being actively performed." The code could contain definitions similar to this one for real estate signs. "Grand opening signs" could be defined as "a temporary sign placed within a parcel of property, not to exceed thirty two (32) square feet, and which may be displayed for a period not to exceed ninety (90) days following the sale, lease, or other conveyance of the parcel or any interest therein." Event-based signs could fall under a regulation that defines an "event sign" as "a sign not to exceed twelve (12) square feet that is placed no 
A. Weinstein

Legal Considerations in Sign Code Development

Interdisciplinary Journal of Signage and Wayfinding; Volume 2; Issue 1

more than two (2) weeks prior to and no more than two (2) days following a registered event," and which requires a registration of events with the permitting jurisdiction.

Assuming the code provided a category for general temporary noncommercial signage, these code provisions would be more likely to satisfy Reed than a code that articulates definitions based solely on the message of signs. Note, however, that the aforementioned provisions have not been tested in courts, and even Reed may call into the question the validity of such regulations under the rationale that these regulations exhibit subtle content bias. Even so, to the extent local governments desire to regulate signs according to function, the authors advise against such regulation, as any type of functional or categorical regulation will lead to increased risk exposure for the local government.

\section{F. Permitting and Enforcement}

As with other areas of regulation, in addition to being informed by the local government's tolerance for risk management, sign regulations should also be based upon the local government's appetite for and ability to enforce the regulations. Enforcement of sign regulations is rarely an easy task, and improper enforcement of sign regulations can lead to serious trouble. ${ }^{29}$ Local governments should therefore consider the enforcement of sign regulations before and during the drafting process, rather than after adoption of the regulations.

The availability of online registration systems may greatly ease enforcement headaches of local governments. For example, it may be possible for a local government to require any person displaying a temporary sign to register the sign with the local government on its website. Such an online registration system would not act as a bar to an individual's right to display a

\footnotetext{
${ }^{29}$ Selective enforcement claims arising in the enforcement of speech regulations may give rise to liability for local governments. See, e.g., LaTrieste Restaurant and Cabaret, Inc. v. Vill. of Port Chester, 40 F.3d 587, 590 (2d Cir. 1994).
} 
A. Weinstein

Legal Considerations in Sign Code Development

Interdisciplinary Journal of Signage and Wayfinding; Volume 2; Issue 1

temporary sign, and would provide the local government with a registry of the properties at which signs are posted, which would in turn allow for better enforcement of size, height, and time restrictions on signs. In such a scenario, the local government could cite property owners with unregistered signs.

With the advent of digital technology, there is significant room for creativity in enforcing sign regulations, so long as the local government is not using such enforcement mechanisms to subvert First Amendment obligations. 
A. Weinstein

Legal Considerations in Sign Code Development

Interdisciplinary Journal of Signage and Wayfinding; Volume 2; Issue 1

\section{Conclusion}

Reed is likely to precipitate a significant shift in courts' treatment of sign codes under a First Amendment challenge. Local governments thus would be wise not merely to consider Reed when developing a dew sign code but to undertake sign code reviews and, if necessary, revise now to ensure that the code does not contain any of the content-based distinctions that created problems for Gilbert. Where necessary, local governments should consult resources-including planners and lawyers knowledgeable in First Amendment issues - to be certain that sign codes do not carry more risk than the local government desires to bear. 